\section{Intersections}

Canadian Journal of Music

Revue canadienne de musique
Intersections CANADIAN JOURAL OF MUSIC

\title{
Eccentric/Exzentrisch: On Gould, Gulda, and Becoming a Cultural Icon
}

\section{Alexander Carpenter}

Volume 37, numéro 2, 2017

URI : https://id.erudit.org/iderudit/1066615ar

DOI : https://doi.org/10.7202/1066615ar

Aller au sommaire du numéro

\section{Éditeur(s)}

Canadian University Music Society / Société de musique des universités canadiennes

ISSN

1911-0146 (imprimé)

1918-512X (numérique)

Découvrir la revue

Citer cet article

Carpenter, A. (2017). Eccentric/Exzentrisch: On Gould, Gulda, and Becoming a Cultural Icon. Intersections, 37(2), 9-25. https://doi.org/10.7202/1066615ar

\section{Résumé de l'article}

Cet article examine comment les icones culturelles sont formées et compare les arrière-plans culturels, les carrières, et les notoriétés de deux des plus talentueux - sinon " excentriques " - musiciens classiques du vingtième siècle : la pianiste et présentateur canadien Glenn Gould, et le pianiste, compositeur, et provocateur autrichien Friedrich Gulda. Gould est une icône canadienne encensée dont les excentricités notoires en tant qu'interprète musical et individu ajoute favorablement au compte de son statut iconique; Gulda, bien que pianiste aux compétences et accomplissements similaires, est vu comme une figure ambivalente - sinon scandaleuse - de l'histoire culturelle autrichienne, précisément à cause de son comportement excentrique et ses performances inclassables.
Copyright @ C Canadian University Music Society / Société de musique des universités canadiennes, 2019
Ce document est protégé par la loi sur le droit d'auteur. L'utilisation des services d'Érudit (y compris la reproduction) est assujettie à sa politique d'utilisation que vous pouvez consulter en ligne.

https://apropos.erudit.org/fr/usagers/politique-dutilisation/ 


\title{
ECCENTRIC/EXZENTRISCH: ON GOULD, GULDA, AND BECOMING A CULTURAL ICON
}

\author{
Alexander Carpenter
}

Comparing the lives and careers of Canadian pianist Glenn Gould and Austrian pianist and composer Friedrich Gulda reveals a wealth of striking similarities and correspondences in their respective attitudes towards music and performance, but also some significant differences in legacy and reputation. They were nearly exact contemporaries-Gould was born in 1932, Gulda in 1930 - and both were revered musicians, ranked among the greatest pianists of the twentieth century. They shared a discomfort, even a disdain for the strictures of the concert culture of the classical tradition, and later in life each engaged vigorously with contemporary media and technology (radio, television, and recording technology in Gould's case; radio, television, and popular music in Gulda's). Both pianists were offered awards in their respective countries for their artistic achievements, and both rejected or returned them. As the title of this article suggests, both Gould and Gulda were regularly described as "eccentric," with much attention-in the popular media, in critical reviews, in biographies, and in scholarly sources-devoted to their aesthetic choices and personalities, including Gould's esoteric repertoire and idiosyncratic interpretive approach, unusual performance requirements, neurotic behaviour and chronic hypochondria, and Gulda's often bewildering genre-bending jazz/pop/ classical pasticcios and his outrageous publicity stunts.

By eccentric, I am referring here to the notion of behaviour or attitudes that are unusual or out of the ordinary, but not necessarily pathological. Etymologically, eccentric derives from the Greek ekkentros, meaning "out of the centre," with reference to cosmology: specifically, to a non-circular orbit, or a circular orbit that does not have the Earth at its centre-"not centrally placed," as the Oxford English Dictionary would have it ("eccentric," OED). As of the late seventeenth century, the word took on a figurative meaning, referring to a person who deviated "from usual methods," or who was "odd, whimsical" ("eccentric," OED). By way of comparison, Duden defines exzentrisch in much the same way as the $O E D$ : cosmologically, as having one's own centre lying outside of the centre of a circle, ${ }^{1}$ and more generally, behaving in an exaggerated

1 “... [mit dem eigenen Zentrum] außerhalb des Kreiszentrums bzw. Drehpunktes liegend” All of the translations in this article are by the author. 
way, or not in the usual way (Duden). ${ }^{2}$ In the cases of Gould and Gulda, eccentric does not describe deviant behaviours or attitudes in the abstract-and certainly not whimsicality - but rather a sense of being-out-of-centre in relation to particular norms. This being-out-of-centre-ness, moreover, arguably underscores a kind of ontological conception of genius, and in particular as it applies to Glenn Gould; with respect to Gulda and Austrian culture, on the other hand, one could argue that the notion of off-centredness is perhaps less important than the notion of violating norms and disturbing the social order, as I discuss below.

Gould, who was revered as a piano virtuoso and genius in his lifetime, since his death in 1982 has become even further elevated into a figure of legendary status-an iconic figure, to be sure-in Canada, notwithstanding his iconoclastic approach to the classical piano repertory, to interpretation, and to the traditions of concert culture. Gulda, on the other hand, while likewise an iconoclast in his attitudes towards performance, genre, and tradition, came to be regarded with some ambivalence and even wariness in his homeland over the course of his career, and by comparison to Gould is certainly a less revered figure in Austrian cultural history. In this article, I examine the lives and careers of these two very similar musicians and offer a critical account of their two very different outcomes. I begin by addressing the idea of cultural icons: how they are defined and how they come into being. I then provide a detailed comparison of Gould and Gulda-their biographies, their careers as musicians, and their statuses as historical-cultural figures. Gould, I would argue, becomes an icon because of his eccentricity: his alien-ness, his other-worldliness raises his stature to that of a kind of pure artist-an "art machine," as the Austrian novelist Thomas Bernhard describes him ${ }^{3}$ - who makes the world better by remaining distant from it; Gulda, by contrast, never achieved the same iconic status because his eccentricity was ultimately not understood as sublimation but rather as transgression, or even a form of cultural terrorism.

\section{Cultural Icons and Cultural Scripts}

The Oxford English Dictionary defines an icon as "a representative symbol, esp. of a culture or movement [i.e. in this case, Western culture, and more narrowly, the culture of Western art music]; a person, institution, etc. considered worthy of admiration or respect" ("icon," OED). While historically, icon relates to "notions of visuality"-an icon is a "sign that resembles or imitates its referent," according to nineteenth-century semiotics (Leypoldt 2010, 5) - the term is used more broadly these days. As David Scott and Keyan Tomaselli have observed, the term icon appears in modern, popular contexts-in the media and in everyday speech-"to signify celebrity or a cult object" $(2009,5)$ or what

2 “... auf überspannte, übertriebene Weise ungewöhnlich, vom Üblichen abweichend.” Interestingly, Duden uses the example of "the lifestyle of artists" as a way to explain exzentrisch: "der Lebensstil des Künstlers ist exzentrisch."

3 "In the end people like Glenn had turned themselves into art machines, had nothing in common with human beings anymore, only seldom reminded you of human beings." See Bernhard (1991, 92). 
Günter Leypoldt calls "iconic personhood" (2010, 7). According to Scott and Tomaselli, an icon "encodes the person or object so identified as personifying the exemplar of a particular generation, a stylistic epoch, and a feeling about a particular set of social experiences ... it is ... a construction, a product deriving from the media, entertainment, or public relations industries ... its origin is in the real [but] the operations to which it is submitted in the iconizing process transform it into a simulacrum" (2009, 17).

Here, apparently drawing upon Baudrillard (1994), Scott and Tomaselli argue that an icon is not a real thing simply elevated or sublimated into a higher status of reality, namely an icon; rather, through the process of becoming an icon, the object/person becomes a simulacrum, a copy of something from reality that, though a copy, is no less real. The image or representation of the thing, in other words, takes on such importance-and a life of its own - that it thus becomes hyperreal, or more real than its original referent (see Baudrillard 1994).

Mike Parker has offered a useful, if somewhat prescriptive definition of cultural icons. According to Parker, cultural icons are always images; they must be "distinct, durable and reproducible"; they "reside in the collective memory of large groups of people"; and they "reveal discernible tragic-dramatic narratives that are formed and received by communities particularly receptive to the development of iconic meaning" (Parker 2012, 12-13). Parker's focus is on the tragic/dramatic human narrative contained within cultural icons; it is this narrative that produces "fixed meaning leading to distinct iconic imagery" (15).

This article, in placing Gould and Gulda side by side, is asking two interrelated questions: Why do these two great musicians not occupy the same status in their respective countries? Why is one an equivocal figure, while the other is a cultural icon? I argue that the accounts of iconicity that I have summarized, above, clearly resonate with Glenn Gould's reputation and legacy, but not Friedrich Gulda's. Gould is a cult figure, as evidenced by the copious popular literature and films devoted to him, and by the hagiographic tone adopted by most of his biographers. ${ }^{4}$ Gould's biographers have elevated him to the status of an artist-philosopher-a romantic hero who was both "crazy" and at the same time evolving from performer to a "thinker about music" (see Mark Kingwell, cited in Intini 2009). Gulda's legacy seems to have been tarnished by his performance activities later in life: an obituary by the Austrian music critic Peter Cossé that celebrates Gulda’s "creative rebelliousness" [schöpferische

4 Gould's website, maintained by the Glenn Gould foundation, lists fourteen major monographs devoted to Gould, and three major films. Gould continues to have a substantial online presence, via his foundation's electronic mailing list, Twitter account, and official YouTube channel (with 103 videos alone). While there is a modest official website devoted to Gulda-maintained by the Musica Kremsmünster Society in Austria-and a fairly substantial body of literature in German concerned with Gulda and his music, along with a documentary film entitled So What? and many performance videos online, there is simply no comparison with Gould. A simple Google search provides a stark contrast: "Friedrich Gulda" yields about 286,00o hits; "Glenn Gould" yields something close to 5.57 million hits; there are approximately 27,000 videos of Gulda on the internet; there are 187,000 videos of Gould. 
Aufsässigkeit] also observes that "Gulda's later years were troubled by eroto-maniacal self-portraits and by the promotion of his increasingly kitschy compositions. He sought to live the high life but, unforeseen, art and his old, long-faithful audience slipped away from him" (Cossé 2000, 75). ${ }^{5}$

Gulda, if also eccentric, was nonetheless regarded as an authentic person: as Hans Sittner recounted, "He says what he thinks, and he thinks a lot about music" (Sittner 1970, 93). ${ }^{6}$ Gould-as-icon, on the other hand, is clearly a simulacrum of the "real" Glenn Gould. The iconic Gould was an unearthly virtuoso with inhuman musical talent and gifts, an "art machine," while the real Gould was an unhealthy, neurotic, socially handicapped loner-the carefully cultivated public image of the eccentric genius was decidedly at odds with the decidedly weird private man. Unlike Gulda, much of Gould's professional life was captured on film, providing a copious photographic and filmic legacy. Edward Said has observed that, although Gould gave up public performance in 1964, he ironically became one of "the most televised, filmed, and recorded musician[s] who ever lived," a paradoxically "garrulous, rococo ... hermit and ascetic" (Said 2008, 196, 4) who could often be seen and heard airing out his ideas in the public eye. Gould's visual image as a performer is itself iconic: he performed seated on a stunted chair, hunched over the piano, his nose nearly touching the keys-this image conveys a very particular kind of intimacy with and connectedness to both the instrument and to the music itself.

Very different from Gulda, Gould fully embodies the Schopenhauerian "tragic-dramatic narrative" that Parker associates with icons, according to which Gould can be seen suffering as the sad genius whose life ended too soon. Gould's life, devoted entirely-and apparently to his physical and psychical detriment-to music and the communication of ideas, is also implicated in the notion of the "tragic action" represented in art, which provides a temporary reprieve from life as merely the will-to-live: "Through art," asserts Parker, "we can-for a fleeting moment-forget that we are driven by a blind will just to exist ... genuine cultural icons are rare instances of public art in this precise sense" (Parker 2012, 11). Gulda was a major figure in the history of piano performance in the twentieth century, a musician, composer, and musical thinker of considerable talent-whose approach to interpretation and piano technique was, in many ways, similar to Gould's (in its focus on structural elements, sparing use of pedal, and generally percussive touch) - and one of a very few who were able to effortlessly shift back and forth between classical music and jazz at the highest professional level. Gould, however, as a "tragic" cultural icon, could, in a sense, symbolize art-or the "tragic action" of art-itself.

One way to contextualize and think about the cultural differences at play in determining the statuses of Gould and Gulda in their respective countries may be through cultural script theory, a relatively recent formulation established

5 "In den letzten Jahren verstörte Gulda mit erotomanen Selbstinszenierungen und als Promotor seiner zunehmend kitschigen Eigenkompositionen. Er suchte das pralle Leben zu fassen und unversehens entglitt ihm die Kunst und leider auch sein altes, lange Jahre getreues Publikum."

6 "Er sagt, was er denkt, und er denkt viel über Musik nach." 
by the linguist Anna Wierzbicka. ${ }^{7}$ Cultural script theory asserts that people in different societies and communities speak differently, and through their differences in speech articulate specific values and hierarchies of values. These different ways of speaking "constitute a behavioral manifestation of a tacit system of 'cultural rule,' or ... ' cultural scripts"' (Wierzbicka 1998, 242). Comparing the language of public signs in different socio-linguistic contexts, for instance (German and Anglo), Wierzbicka demonstrates how such language constitutes a cultural script that can assist outsiders in grasping the "cultural logic" of a given group (242). In the case of German-and Austrian-culture, she argues, public signs point to the continuity of traditional Germanic values such as "the value of social discipline, and Ordnung (order) based on legitimate authority, [which] are far from obsolete" (242). While she observes that Austrians and Germans have a different "ethnography of speaking," Michael Clyne has argued that one aspect of this difference, namely the use of professional and educational titles in Austria-which is far more prevalent than in Germany, and in Austria titles can also be transferred from husband to wife-points to a particular "hierarchical class system and acceptance of authority" in Austrian culture (quoted in Wierzbicka 1998, 273). And while stereotypes-such as the Austro-Germanic preference for order and authority, and the valuing of social cohesion-are problematic, Wierzbicka notes that they are difficult precisely because they "are often partly true" (246).

While this article in not concerned with linguistics, the deployment of language and its meaning differs between social contexts, and these differences speak to specific cultural norms and values. With Gould and Gulda, what may be at stake are very different meanings and valuations of the concept of "eccentricity": in an Austro-Germanic context, it may be perceived as a kind of social deviance; in an Anglo context, where "personal autonomy" is a cultural script, it may be seen as a positive assertion of individualism (Wierzbicka 1998, 247).

What follows is a comparison of the lives, careers, and reception history of Gould and Gulda, in order to critically reassess the legacies of two of the most important musicians of the twentieth century, and thereby gain better understanding of both the nature of cultural icons and some of the essential differences between Canadian and Austrian cultural histories.

\section{GLENN GOULD}

Glenn Gould has been the subject of countless scholarly and popular biographies, museum exhibitions, several feature films and, most recently, a stage play. ${ }^{8}$ He has a vast back-catalogue of recordings, and his performances are still regularly heard on radio. During his lifetime, he was nominated for six and won three Juno awards, and immediately following his death, he was inducted into

7 I am grateful to one of the reviewers of this article for suggesting cultural script theory as a tool for this inquiry.

8 The music journalist Tom Payne, echoing Said, notes the irony of the vast array of biographical material devoted to Gould, given that, as a concert pianist, he gave only 200 performances and died at the age of fifty (Payne 2004). 
the Canadian Music Hall of Fame. In 1970 he was offered the Companion of the Order of Canada, one of the country's highest awards, but turned it down, insisting he was too young to receive it. Today there is of course a Glenn Gould School in Toronto, along with a Glenn Gould Foundation that honours Gould's legacy by promoting music through events and prestigious prizes.

Gould was a child prodigy who reputedly began playing the piano at home at the age of three, under the tutelage of his mother. His formal studies began at the Royal Conservatory of Music in Toronto at the age of ten. Within three years, he had completed the conservatory's curriculum, passing all of his exams and graduating, effectively, as a professional pianist at thirteen. Gould made his professional debut with the Toronto Symphony at fourteen, playing Beethoven's Piano Concerto no. 4. He toured the world as a concert pianist throughout his twenties, notably giving concerts in Western Europe, Israel, and the Soviet Union in the late 1950s; however, his concert career was derailed a number of times during those years as the result of recurring-perhaps partially psychosomatic-illnesses that forced him to cancel a number of concerts. ${ }^{9}$ Gould gave up performing in public for good in 1964, after which time he became increasingly involved with documentary film and radio programs, in writing essays and articles on musical and non-musical topics, and in recording technology. The years following his retirement from the concert stage have been characterized by Edward Said as a "rebirth," and indeed Gould himself called the studio "womblike": his post-1964 years also saw a marked "displacement of emphasis," away from the demands of a paying concert-hall audience and towards the recording studio as a site of creativity and interpretation, of paradoxically "passionate ... antisensuality," and a respite from the demands of the commercial music market and the whims of audiences (Said 2008, 9). Gould continued making radio and film programs and recording music in recording studios up until his death from a stroke in 1982.

Gould became famous for his renditions of Bach and Beethoven, but he was also known for championing modern music, especially the works of the Second Viennese School, comprising Arnold Schoenberg, Anton Webern, and Alban Berg. ${ }^{10}$ Said has celebrated Gould's "interesting and wide-ranging repertory," which was quite unlike any other pianist of his stature, including as it did the keyboard music of the late-Renaissance and some of the major baroque and classical composers-though not Mozart, whom Gould famously disdainedbut relatively little from the mainstays of the piano repertory, namely the major composers of the nineteenth century, including Schubert, Schumann, and Chopin.

The influence of Schoenberg's modernism on Gould is clearly evident not only in Gould's highly refined technical and analytical approach to music-an

9 Georges Leroux argues that Gould's illnesses were likely a symptom of his increasing dissatisfaction with touring and performing for audiences (Leroux 2010, 36-7).

10 Ironically, though, Gould did not seem to have liked Vienna very much: it was hard to find a place to practise, as there were too many concerts going on, and he found the city "much less attractive than I had imagined it. Too much rococo architecture for my rather severe tastes" (quoted in Ostwald 1997, 158). 
"ascetic" and "anti-romantic" approach, with a focus on the formal features (Leroux 2010, 74)-but also in his turning away from public performance in the mid-196os. Gould gave up public performance at the peak of his career as a young virtuoso soloist at a time when he was worshipped by many of the great pianists of the century-including Arthur Rubenstein, Van Cliburn, and Sviatoslav Richter-and when critics were declaring him the greatest pianist since Ferrucio Busoni and a musician without equal among his contemporaries (Bazzana 2003, 233). Gould claimed to "detest audiences" and felt concert culture comprised a kind of "mob" rule analogous to gladiatorial games, in which the audience has a "sadistic lust for blood," waiting for a performer to fail-he felt performance should be, ideally, like a private "love affair" and "not a contest" (179-80).

This view of the audience-performer relationship echoes Schoenberg's radical response to hostile audiences of modern music in Vienna. In 1918 Schoenberg inaugurated his Society for Private Musical Performance, the purpose of which was to give modern music a fair hearing by private audiences of connoisseurs. Schoenberg's aim for his music society, which decried the "corrupting influence of publicity" and the competitive elements of concert performances, was to foster a silent audience that was engaged in focused listening to repeated rehearsals and performances of new music: no signs of approval or disapproval were permitted (see Auner 2003, 151). Gould himself clearly expressed an explicitly Schoenbergian view of concert culture in 1962, in an essay entitled "Let's Ban Applause." In this essay, Gould advocates a silent, contemplative audience experience that emphasizes subjective engagement with music's inner meanings-"aesthetic narcissism"-rather than the "shallow" engagement with a concert as a mere theatrical event: "The purpose of art is not the release of a momentary ejection of adrenaline but is, rather, the gradual, lifelong construction of a state of wonder and serenity" (quoted in Leroux 2010, 74).

Gould's musical interpretations were one aspect of his "eccentricity." His recordings of Bach, especially, are highly idiosyncratic, and listeners either greatly value and respect Gould's analytical approach, which separates out, almost forensically, individual parts and focuses on structure and the clear presentation of each voice, or they disdain and dismiss it for its unusual tempi, its staunchly rhythmic emphasis, and for its cool, detached, highly modernistic character. French pianist Pierre-Laurent Aimard has recognized Gould as an intelligent, clever musician and an "interesting phenomenon," but has decried his recordings for their

motoric, automatic approach to tempo ... there is no flexibility in the way he phrases the melodies and harmonies ... [I am irritated by] the mannerisms and the affectations of his playing. What you are aiming for, as a listener, is to forget about the performer, to listen just to the music, but in Gould's playing, there is too much that disturbs to forget about him. There are many clever and commercial reasons for the cult of Gould that existed during his lifetime and still does now. I'm not a fan nor a member of that club ... Gould is certainly not a person who plays Bach's music in a way that is without question marks. (quoted in Service 2012) 
Here, Aimard highlights a common criticism of Gould's playing and interpretive approach to music, namely that, as a result of Gould's "mannerisms and affectations"- his percussive, detached playing, rigid phrasing, humming, rapid tempi, and so on-the listener is always made forcibly aware that he is listening to Gould, rather than, say, Bach or Mozart: this criticism of Gould characterizes him, in a sense, as too present in his performances, coming between the listener and the composer's intentions.

The ambivalence towards Gould's recordings of Bach is distilled into a more open hostility when his performances of Mozart or Beethoven are examined. The music critic Tom Service has described Gould's interpretation of Mozart as "willfully idiotic" (Service 2012), or so terribly incoherent that it seems to be some sort of manifestation of Gould's distaste for Mozart at the keyboard; the Swiss pianist Francesco Piemontesi argues that Gould's Mozart readings "cross every line in terms of form, structure, harmony and musical language. The price for singularity is too high for my own taste" (quoted in Service 2012). And the Canadian pianist Angela Hewitt has observed, "With Gould ... there are wonderful things and horrible things. You wonder why he played Mozart the way he did" (quoted in Service 2012).

Gould's striking idiosyncratic performance aesthetic and his sharp disdain for the concert-going public, as described above, are among the many aspects of his character and behaviour that contributed to his reputation as an eccentric. He was infamous for dressing in warm clothes-scarf, overcoat, and gloves-all year round; he sat on a very low chair, hunched over the piano; and he often sang or hummed when he played. He was a hypochondriac who lived alone and ate the same food every day. Among Gould's best-known eccentricities was his habit of calling friends and acquaintances in the middle of the night and expecting them to talk with him on the phone for hours. Gould was reputed to be "emotionally restricted and puritanical" (Ostwald 1997, 145) and unable "to adjust to the simplest of demands, a congenital incapacity to adapt" (Leroux 2010, 55). While Gould was not "maladjusted," he was nonetheless "narcissistic" and "idiosyncratic"-indifferent to everyday life, as evidenced by "his ill-fitting clothes, his choice of diet, his nocturnal life in the silence of his apartment, the disorder that seemed central to his existence [and] his phobias" (Leroux 2010, 55).

The conductor George Szell, after working with Gould in 1957, is famously reputed to have exclaimed in frustration, "That nut's a genius." This quotation appears in nearly every biographical account of Gould, as does the word eccentric. To some extent, surely Gould, aware of the publicity opportunities offered by his eccentricities, cultivated a Romantic image of an unworldly artist, removed from the workaday world; however, I would argue that Gould, notwithstanding his aversion for the composer, was decidedly Schumannesque in his deportment as a Romantic artist, especially in his construction of a number of alter egos-among them the New Jersey cab driver Theodore Slutz, the German composer Karlheinz Klopweisser, and the English conductor Sir Nigel Twitt-Thornwaite-who served as flamboyant critics and commentators on 
television, radio, and in print. ${ }^{11}$ Although Gould's behaviour and ideas arguably turned towards the truly neurotic as he got older-phobias concerning illness, physical contact, and sexual intimacy-ultimately audiences accepted his many "eccentricities" in the face of his staggering technical prowess, highly original interpretations, and desire to elevate musical performance into an intellectual-critical art.

\section{Friedrich Gulda}

While I am a scholar and devotee of Viennese cultural history, and a frequent visitor to the city and especially to its concert halls, I had never heard of Friedrich Gulda before the spring of 2012. ${ }^{12}$ I was attending a concert at Vienna's Musikverein in May to hear chamber arrangements of early twentieth-century Viennese music by Schoenberg and Webern. Included on the program was, as it happened, one of Gulda's better-known pieces, his Concerto for Cello and Wind Orchestra, composed in 1980. It is a stunning piece of music, not only because of the virtuoso cello part, but also because of the audacious juxtaposing of disparate musical styles: from modernist atonality to big band swing, from jazz rock to Mozartian minuet, from circus march to Bach chorale. The piece makes a strong first impression: it is tuneful, rhythmically vivacious (the small orchestra includes a drum kit), surprising, light-hearted, and stylistically promiscuous. The Concerto for Cello and Wind Orchestra is, in fact, emblematic of Gulda's approach to composition, an approach that draws freely from a variety of genres and is rooted in a kind of (post)modernism that eschews the gravitas of the Austro-Germanic tradition-a gravitas represented by Schoenberg and his school, with its strong insistence on tradition, structure, and polyphony, and inherited by Glenn Gould.

It was not as a composer but as a concert pianist that Gulda became famous. He does not appear to have been a child prodigy of the same order as Gould; the early indications of his musical aptitude and his early studies seem, in comparison to Gould's origin story-a child so musical that he hummed rather than cried as an infant-to be rather jejune. Gulda, however, did begin his piano studies relatively early-at around the age of seven-and he was able to launch a professional performance career as a teenager; at sixteen he took first prize at the Geneva International Music competition and performed with the Vienna Symphony (he played Beethoven's Piano Concerto no. 4, the same work with which Gould made his professional debut at fourteen). Gulda toured

11 Michael Stegemann has provocatively described these two dozen alter egos, behind which Gould "hid ... in make-up and costume before the camera, with a distinctive accent before the microphone and with a choice use of words on paper" as a "gift to any psychoanalyst" (Stegemann 2015).

Georges Leroux argues that while Gould "spurned that repertoire that was impervious to his asceticism [i.e., Romantic music]," he was nonetheless capable of playing with "an exquisite lyricism," making musical lines "sing"; Gould's explanations of his aesthetic choices seem to "militate against romanticism," but in the end it is in fact the Romantic "hints of melancholy" that draw us so powerfully to Gould's playing and interpretations (2010, 74).

12 Admittedly, I am an outsider with respect to Viennese culture, so my anecdote should be read and understood in that context. 
Europe and South America in his late teens, and by age twenty had made his debut at Carnegie Hall.

Gulda was highly regarded for his interpretations of the great Viennese classical repertory-Mozart and Beethoven especially-but also for his performances of Bach, including two recordings of The Well-Tempered Clavier. As New York Times music critic K. Robert Schwarz observed, Gulda's performances of the Austro-Germanic classics "reflected [his] innate tendencies [to shun] excessive showmanship, favoring an intellectual, objective stance," with a sometimes "brutal[ly]" heavy touch that "chiseled" out the textures and melodic lines in a piece (Schwarz 1985). Gulda is counted among the very best pianists of the past century. His recordings are, in fact, included in Philips's definitive Great Pianists of the Twentieth Century recording series, and the influential American music critic Harold C. Schonberg argued that Gulda represented "a continuation of the great German traditions of piano playing exemplified by Schnabel and Backhaus" (quoted in Kozinn 2000).

As a classical pianist, Gulda recorded many works from the standard piano repertory, from Bach to Beethoven to Schumann to Debussy. He was awarded the Austrian Medal for Science and Art in 1959, at the age of twenty-nine, in recognition of having "distinguished [himself] and [having] earned general acclaim through especially superior creative and commendable services in the areas of the sciences or the arts." Ten years later, in the summer of 1969, the Vienna Music Academy offered Gulda the Ring of Honour at the Vienna Beethoven Competition: a staunch critic of the Austrian music education system, he returned the ring a few days later, a gesture viewed as scandalous by the Austrian press. ${ }^{13}$

Gulda's career and reputation as a classical musician were damaged by his turn towards jazz in the 1950s, when he began playing, in something of an ad hoc fashion, with jazz bands while on concert tours-though, as Gulda insisted, the poor reception was primarily in professional circles, in the trade press, and from reviewers, not by concert-goers (Baier 1990, 226). ${ }^{14}$ By the latter part of the 1950s, Gulda was including improvised jazz pieces in his recitals, had taken up the baritone saxophone, and had opened a successful jazz club in Vienna. While he continued to perform as a classical pianist, in 1962 he felt a "sudden discontentment at continuing the career of an acclaimed soloist, and set out to explore new means of communication" (Brunner and Elste 2017). He opened a music school specializing in teaching improvisation, founded a jazz competition, and began performing with various jazz groups. By the 1970s Gulda's recital programs had become an unpredictable blend of traditional classical works, original compositions, jazz pieces, and improvisation.

Gulda never entirely abandoned classical music or jazz: his later recordings included Mozart concerti and Beethoven sonatas, along with collaborations

13 Gulda accused the Wiener Musikakademie of hypocritically awarding a prize named after the revolutionary Beethoven while fostering students who were slavish parrots, incapable of creativity and improvisation. For the full text of Gulda's speech, see Musica Kremsmünster (2017).

14 “'Rezeptionsschwierigkeiten waren bei meinem Publikum immer schon deutlich geringer,' gesteht er, 'als bei der Fachwelt, der Fachpresse, den Rezensenten'." 
with Chick Corea-including a 1982 concert in Munich captured in the film Chick Corea and Friedrich Gulda: The Meeting-and Joe Zawinul, and he went on to explore various approaches to Third Stream. In the 1990s he turned, unpredictably again, towards popular music, becoming involved in techno music and DJ culture in the years leading up to his death.

Opinions about Gulda, as one might imagine, are decidedly polarized. While he celebrated himself as "the most important creative musician of the second half of our century"15 for rescuing music from high modernism and what he derided as the "dead-end of dodecaphony and other unworldly music and misanthropic practices"16 (quoted in Spiegel Online 2000), and was heralded in his obituaries as "one of Austria's foremost classical and jazz pianists," he was also criticized, during and after his lifetime, as a "terrorist pianist" for his genre-bending, non-traditional, highly provocative approach to music and performance (Woodstra, Brennan, and Schrott 2005). He was regularly described by critics and commentators as a "boundary crosser" [Grenzüberschreiter or Grenzverletzer] who openly courted controversy. Austrian music journalist Herbert Hopfgartner has perhaps best captured the essence of Gulda's divided reputation by describing him in a recent article as "the 'wild philosopher' who expanded 'musical geography"'17 (Hopfgartner 2010, 12). Critics of Gulda's classical recordings accuse him of treating art music as though it were jazz: his recordings of Debussy have moments reminiscent of jazz vamping, and he was excoriated for playing Chopin's ballades without "poetry or understanding" and "to be waiting impatiently for the moment when he can bang off into specious virtuosity" (quoted in Summers 2017).

My focus here is on Gulda's reputation as an "Exzentriker." Like Gould, Gulda pulled away from the strictures of classical music performance and the expectations of audiences and the music business alike, though in Gould's case, as we have seen, this behaviour contributed positively to the mythology that came to surround him and that built him up into an icon. Gulda, on the other hand, was characterized by the Austrian media as snubbing both audiences and the industry through his eccentricities and by his refusal to dress appropriately or to receive awards: "Gulda's eccentricity was notorious: from formal dress codes to awards, he refused to adopt the traditional practices of the music industry, rebuffing organizers and audiences on a regular basis"18 (ORF n.d.). Gulda, like Gould, dressed like an eccentric, but again, with what seemed to be the intention to provoke: just as concert-goers could never be certain what Gulda might play at a given performance (or, indeed, if he was even going to show up), they likewise could not guess how he would dress. He often wore casual rather than formal clothing for recitals and concerts-Hawaiian

15 “... der wichtigste kreative Musiker der zweiten Hälfte unseres Jahrhunderts."

16 "... Sackgasse der Zwölftönerei und andere weltfremder musik- und menschenfeindlicher Praktiken.”

17 “... der 'Wilde Denker' oder 'die Erweiterung der musikalischen Geographie.”'

18 "Berühmt-berüchtigt war Guldas Exzentrik: Er verweigerte die gängigen Praktiken des Musikbetriebs vom Frackzwang bis zu Auszeichnungen und brüskierte immer wieder Veranstalter und Publikum." 
shirts, jeans, peaked caps, and Bucharian hats-and was famously described in a concert review as looking like a "Serbian pimp." 19 Gulda is also reputed to have given at least one concert-a performance of Schumann's songs arranged as recorder duets-in the nude (Blom 2000). Like Gould, Gulda also cultivated at least one alter ego, a singer named Albert Golowin: beginning in 1969, the same year he was awarded the Ring of Honour at the Beethoven Competition, Gulda took to wearing a false beard and wig when photographed as Golowin, and recorded a jazz album entitled Donau so blue in 1970 in collaboration with Golowin in an apparently deliberate attempt to deceive listeners and the musical press into thinking he and Golowin were two different people. ${ }^{20}$ While Gulda, like Gould, became tired of the constraints of classical concert life, he did not give up live performance: rather, he continued to perform in various capacities-not only as a classical pianist, but also as a jazz pianist, flautist, saxophonist, and even in collaboration with techno musicians-until his death at the age of seventy, in early 2000.

Gulda's eccentricities-and, like Gould, exzentrisch is a word that is found in virtually all accounts of Gulda's life and work-differ from Gould's in that they do not seem to have been pathological; indeed, they seem to have been instead a corollary of his highly principled views of music and genre, performance, and the musician-audience relationship. Gulda's public behaviour, however, which Allan Kozinn has characterized as "misguided antics" (2000), hurt Gulda's career in ways that Gould's eccentricities never did. Gulda had trouble being taken seriously by both classical and jazz audiences-he has been characterized as a "lone wolf" who was not truly at home in any camp, not even the progressive third-stream community (see Woodstra, Brennan, and Schrott 2005) - and his attempts to garner attention for himself and his music earned him a reputation as a sort of rebel-clown: in the Austrian and German media, he could be at once described as "[for over forty years] one of the most celebrated pianists in the world," but also caricatured as "Rebelle, Diva, Unorthodoxer" (Müller 1989). ${ }^{21}$ By the end of his life, Gulda's reputation was, as Austrian journalist Gerald Heidegger surely understates the case, "somewhat battered" [einigermaßen ramponiert], thanks in large part to pranks like his notorious "Resurrection Party" - which included a troupe of go-go dancersheld in Salzburg in 1999, shortly after he had reported his own death to the media (Heidegger 2017). Gulda's eccentricities, while designed to offend society, were also at odds with his intuitive approach to music: Gulda's recordings of Mozart's piano sonatas, for example, are "naked," performed without pretence in order to allow the music to speak gently and clearly for itself, to be true to the composer's original intentions. This is in sharp contrast to Gould's highly subjective, aggressively idiosyncratic, and generally unpopular interpretations of Mozart:

19 This quote appears in numerous places on the internet, but I cannot find its source.

20 See Flamme $(2006,9)$.

21 “... seit über vierzig Jahren einer der am moisten gefeierten Pianisten der Welt.” 
Mozart and his interpreter are ideally related souls. Friedrich Gulda could fall into this category: the intuitive-inspired approach to music contrasts sharply with the eccentricity of shocking the world at inconvenient moments.

However, he never chops up the work with his interpretation in the style of a Glenn Gould. Gulda shows, especially in the Sonata in C major (KV 330), a thoughtful, almost melancholic Mozart, in a manner that may possibly remind some of Schubert.

Yet Gulda remains consistent in the dissection of his spiritual mentor. How could Mozart have thought of this passage or that passage? seems to be Gulda's question. Of course, his interpretation is one more personal interpretation and therefore not universally valid. ${ }^{22}$ (Heidegger 2017)

As a pianist, Gould was always unmistakably and audibly Gould, whereas Gulda, arguably a virtuoso of the same order as Gould, was anything but an eccentric in the interpretation of the classical repertory. One of his recordings of the Beethoven piano sonatas was described by critics as "architecturally clear, rather objective, and often quite astonishing in its uncomplicated directness" (Summers 2017), and he was widely regarded as "one of the most important interpreters of the postwar period" (Blom 200o); Gulda himself characterized his approach to the Viennese classical repertoire, and specifically Beethoven, as "unconditionally faithful to the text [unbedingte Texttreue]." However, Gulda struggled for recognition and acceptance in Austria for much of his career. Ultimately, he would describe his own life as one continuous scandal-indeed, his book of conversations with Kurt Hofmann is entitled Mein ganzes Leben ist ein Skandal-and, frustrated by a lack of understanding from critics and the public, he would assert, "To be somebody important in Austria, first you have to be dead" (Mirow and Leipold 2007).

\section{Conclusion}

The professional and artistic paths taken by Glenn Gould and Friedrich Gulda led to very different legacies and posthumous statuses-Gould is now a cultural icon, while Gulda is not-despite their many similarities. This is attributable, I suspect, to a number of factors. Gould was a classical music wunderkind in a culture-Canada-that does not have the same historical connections to art

22 "Mozart und sein Interpret-das sind im Idealfall verwandte Seelen. Friedrich Gulda könnte in diese Rubrik fallen: Der intuitiv-genialische Zugang zur Musik kontrastiert scharf mit der Exzentrik, die soziale Welt vor allem in ungünstigen Momenten vor den Kopf zu stoßen.

Nie zerhackt er aber mit seiner Interpretation das Werk in der Manier eines Glenn Gould. Gulda zeigt, gerade bei der Sonate in C-Dur (KV 330), einen nachdenklichen, fast melancholischen Mozart. Möglich, dass da mancher schon an Schubert denkt.

Doch Gulda bleibt konsequent im Sezieren seines geistigen Mentors. Wie könnte Mozart diese oder jene Passage gedacht haben? scheint Guldas Frage zu lauten. Natürlich ist auch seine Interpretation eine persönlich und damit nicht allgemein gültige. 
music that Austria does: Gulda's performance choices and flouting of concert traditions may have offered a direct challenge to Austrian cultural memory and identity, while Gould's iconoclasm and eccentricities counted positively towards his Canadian identity. Moreover, Gould's activities were sanctioned and promoted by government-run national media in Canada-especially the Canadian Broadcasting Corporation (the $\mathrm{CBC}$ ) - for many years, and his legacy as a performer was, if anything, sanctified by his subsequent activities as a broadcaster and documentarian for the CBC. Finally, to return to Mike Parker's theory of cultural icons, I would argue that Gould comes close to fulfilling a "paradigm," similar to other iconic figures, like Elvis or Che Guevara: Gould as the embodiment of a type of figure-the artist detached from the world-in the tragic-dramatic narrative of iconicity (Parker 2012, 16). Furthermore, as Parker describes, cultural icons require a "receptive community," which Gould had-indeed, which he helped to create through his eccentricities: the "cult" of Glenn Gould-but that Gulda, the creatively pluralistic inheritor of a well-established and highly conservative musical tradition, may have alienated.

Indeed, Gulda's musical eccentricities may ultimately be at the root of his ambivalent legacy in Austria. Gould's interpretations were stylistically idiosyncratic, whereas Gulda arguably went much further by bending and blending genres. For a highly conservative listening public that venerated Gulda's reverent interpretations of classical piano repertoire, his willingness to challenge and even transgress generic borders-thereby placing classical masterworks on a level playing field with jazz and even popular music-was perhaps beyond mere eccentricity, but rather an openly hostile act: an act of "terrorism," a sin greater than Gould's stylistic-interpretive peccadillos. ${ }^{23}$

Finally, the "process of iconic formation" (16), as Parker describes it, includes emolliation, or the scrubbing out of "harsher biographical details": Gould's increasingly pathetic neuroses were subsumed under the rubric of "eccentricity" and resigned to the shadows or at least "put up with," as Said argues $(2008,3)$, whereas Gulda's iconoclasm was frequently-and in a negative light-at the foreground of his identity as a musician and performer, though his reputation as a "terrorist" or "anarchist" musician may yet be rehabilitated if more scholarly attention is paid to his legacy as a performer and composer.

"One would be hard pressed," writes music critic Hannis Brown, "to find two figures of 2oth century 'classical' music as brilliantly eccentric-both personally and in the concert hall-as pianist/composers Friedrich Gulda and Glenn Gould," but "outside of their personal and performance eccentricities, and an eventual avoidance of Romantic repertoire," he continues, "the two took nearly opposite musical directions" (Brown 2012). Brown locates Gould and Gulda at opposite ends of the spectrum of eccentricity, which is perhaps reasonable enough for now; however, ongoing scholarly effort-especially a thoroughgoing critical assessment of Gulda's life and work-is called for, such that we

23 As Christian Baier asserts, Gulda was an artist who did not so much cross borders as refuse to recognize that they existed: "die nicht bloß Grenzen überschreiten, sondern ganz im Gegenteil sie gar nicht anerkennen” (Baier 1990, 226). 
might have a clearer picture of the influence and legacies of both musicians, and that we might perhaps better understand the relationships between Austrian and Canadian culture, and between musical tradition and what is called "eccentricity."

\section{REFERENCES}

Auner, Joseph. 2003. A Schoenberg Reader: Documents of a Life. New Haven, CT: Yale University Press.

Baier, Christian. 1990. "Friedrich Gulda-wider die 'Musikalische Apartheid." Österreichische Musikzeitschrift, 45 (5): 226.

Baudrillard, Jean. 1994. Simulacra and Simulation. Translated by Sheila Faria Glaser. Ann Arbor: University of Michigan Press.

Bazzana, Kevin. 2003. Wondrous Strange: The Life and Art of Glenn Gould. Toronto: McClelland \& Stewart.

Bernhard, Thomas. 1991. The Loser. Translated by Jack Dawson. New York: Vintage International.

Blom, Philipp. 2000. "Friedrich Gulda." Guardian, 1 February, http://www.theguardian.com/news/200o/feb/o1/guardianobituaries.

Brown, Hannis. 2012. "Two Ends of Eccentricity: Gulda and Gould." WQXR/Q2 Music. https://www.newsounds.org/story/222679-polarization-gould-and -gulda/.

Brunner, Gerhard, and Martin Elste. 2017. "Gulda, Friedrich.” Oxford Music Online. Grove Music Online. http://www.oxfordmusiconline.com/ subscriber/article/grove/music/12018.

Cossé, Peter. 2003. "Nachruf: Genialität und Diminuendo-zum Tod von Friedrich Gulda." Österreichische Musikzeitschrift 55 (3): 75.

Cott, Jonathan. 1984. Conversations with Glenn Gould. Chicago: University of Chicago Press.

Flamme, Friedhelm. 2006. Der Pianist und Komponist Friedrich Gulda: Studien zu Repertoire und kompositorischem Schaffen. Göttingen: Cuvillier Verlag. https://friedhelmflamme.org/wissenschaftler/friedrich-gulda/rezension/.

Heidegger, Gerald. 2017. "Ein Zwiegespräch mit Mozart." ORF.at, https:// newsvi.orf.at/o60124-95785/9579otxt_story.html.

Hopfgartner, Herbert. 2010. "Friedrich Gulda, 1930-2000, der 'wilde Denker' oder die 'Erweiterung der musikalischen Geographie." Musikerziehung 63 (3/4): 12-17.

Intini, John. 2009. "Glenn Gould Was Also a Brilliant Philosopher." Maclean's, 1 October, https://www.macleans.ca/culture/books/the-key-to-his-genius/. Kozinn, Allan. 200o. "Friedrich Gulda, 69, Classical-Music Rebel." New York Times, 29 January, http://www.nytimes.com/2000/01/29/arts/friedrich -gulda-69-classical-music-rebel.html.

Leroux, Georges. 2010. Partita for Glenn Gould: An Inquiry into the Nature of Genius. Translated by Donald Winkler. Montreal and Kingston: McGill-Queen's University Press.

Leypoldt, Günter. 2010. "Introduction: Cultural Icons, Charismatic Heroes, Representative Lives." In American Cultural Icons: The Production of 
Representative Lives, edited by Günter Leypoldt and Bernd Engler, 5-28. Würzburg: Königshausen \& Neumann.

Marsh, John. "Glenn Gould, the Solitary Genius." 2013. In The Canadian Encyclopedia. Historica Canada. https://www.thecanadianencyclopedia.ca/ en/article/glenn-gould-the-solitary-genius-feature.

Mirow, Benedict, and Fridemann Leipold, directors. 2007. So What?! Friedrich Gulda: A Portrait [Universal/Music/DVD]. Germany: Deutsche Grammophon (0440 0734376 o).

Müller, André. 1989. "Ich will keine lebende Leiche sein." Die Zeit 23, 2 June. http://www.zeit.de/1989/23/ich-will-keine-lebende-leiche-sein.

Musica Kremsmünster. 2017. "Friedrich Gulda: Biography." http://www.gulda. at/english/biographie/text.htm.

OED [Oxford English Dictionary]. 2018. s.v. "eccentric."

——. 2018. s.v. "icon." http://www.oed.com/view/Entry/go879? redirectedFrom $=$ icon\&.

ORF [Österreichischer Rundfunk]. n.d. "Gulda, der Exzentriker." http:// newsv1.orf.at/060124-95789/95791txt story.html.

Ostwald, Peter F. 1997. Glenn Gould: The Ecstasy and Tragedy of Genius. New York: W. W. Norton.

Parker, Mike. 2012. "Cultural Icons: A Case Study Analysis of Their Formation and Reception." PhD diss. University of Central Lancashire.

Payne, Tom. 2004. "Most of All, He Hated Applause." Telegraph, 2 May, https://www.telegraph.co.uk/culture/books/3616584/Most-of-all-he-hated -applause.html.

Said, Edward W. 2008. Music at the Limits. New York: Columbia University Press.

Schwarz, K. Robert. 1985. "Gulda Reasserts His Claim to Fame." New York Times, 29 September, http://www.nytimes.com/1985/09/29/arts/gulda -reasserts-his-claims-to-fame.html.

Scott, David, and Keyan G. Tomaselli, eds. 2009. Cultural Icons. Walnut Creek, CA: Left Coast.

Service, Tom. 2012. "Glenn Gould: A Willfully Idiotic Genius?" Guardian, 20 September, http://www.theguardian.com/music/2012/sep/2o/ glenn-gould-wilfully-idiotic-genius.

Sittner, Hans. 1970. "Über Friedrich Gulda.” Beethovenjubiläum: 100 Jahre Musikverein-Schauspielfestival. Vienna: Verlag für Jugend und Volk.

Spiegel Online. 2000. "Pianist Friedrich Gulda ist tot." Spiegel Online, 27 January, http://www.spiegel.de/kultur/musik/ nachrichtenagenturen-pianist -friedrich-gulda-ist-tot-a-62020-druck.html.

Stegemann, Michael. 2015. "Glenn Gould from A to Z: Alias." Sony Music Entertainment, https://web.archive.org/web/20150208025033/http://www. glenngould.com/us/glenn-gould-atoz.

Summers, Jonathan. 2017. "Friedrich Gulda." Naxos Rights International (A-Z of Pianists, Naxos 8.558107-10). http://www.naxos.com/person/Friedrich Gulda 8107/8107.htm. 
Wierzbicka, Anna. 1998. "German 'Cultural Scripts': Public Signs as a Key to Social Attitudes and Cultural Values." Discourse \& Society 9 (2): 241-82.

Woodstra, Chris, Gerald Brennan, and Allen Schrott, eds. 2005. All Music Guide to Classical Music: The Definitive Guide to Classical Music. San Francisco: Backbeat Books.

\begin{abstract}
This article considers how cultural icons are formed and compares the cultural backgrounds, careers, and reputations of two of the most talented-if most "eccentric"classical musicians of the twentieth century: Canadian pianist and broadcaster Glenn Gould, and Austrian pianist, composer, and provocateur Friedrich Gulda. Gould is a celebrated Canadian icon whose well-publicized eccentricities as a musical interpreter and an individual count favourably towards his iconic status; Gulda, while a pianist of similar skill and accomplishments, is regarded as an ambivalent-if not scandalousfigure in Austrian cultural history, precisely because of his eccentric behaviour and genre-bending performances.
\end{abstract}

\title{
RÉSUMÉ
}

Cet article examine comment les icones culturelles sont formées et compare les arrièreplans culturels, les carrières, et les notoriétés de deux des plus talentueux - sinon «excentriques" - musiciens classiques du vingtième siècle: la pianiste et présentateur canadien Glenn Gould, et le pianiste, compositeur, et provocateur autrichien Friedrich Gulda. Gould est une icône canadienne encensée dont les excentricités notoires en tant qu'interprète musical et individu ajoute favorablement au compte de son statut iconique; Gulda, bien que pianiste aux compétences et accomplissements similaires, est vu comme une figure ambivalente - sinon scandaleuse - de l'histoire culturelle autrichienne, précisément à cause de son comportement excentrique et ses performances inclassables.

\section{BIOGRAPHY}

Alexander Carpenter is a musicologist and music critic. He is a professor of music at the Augustana campus of the University of Alberta. Dr. Carpenter holds a PhD in historical musicology from the University of Toronto, an MA in music criticism from McMaster University, and a BMus from Brock University. 